\title{
Al-Maliki Tribal Policy and the Emergence of the New Shaykhs in Iraq
}

\author{
Haidar Reda \\ Chiba University, Chiba, Japan
}

\begin{abstract}
The state collapse in Iraq after the US invasion in 2003 resulted in a vacuum of state institution. This helped the emergence and increase of sectarian violence between Shia and Sunni, which led to civil war in 2006-2007. In order to end the violence and to alienate Al-Qaeda, the US authorities and Iraqi government began supporting tribal leaders during the civil war. In 2008, the Iraqi Prime Minister Nuri Al-Maliki created tribal council called (Majālis al-Asnād) to utilize the tribal groups mainly belong to Shia sect. This article tries to explain the emergence of new social strata called New Shaykhs in Iraqi society, as a result of Maliki's tribal policy. It is due to the failed state situation in Iraq since 2003 which helped non-state actors to be more and more active, such as new tribal leaders. This paper focus on the political manipulation of tribal societies which is different after 2003, compared to traditional policy in Iraq which have used and mobilized the tribal societies.
\end{abstract}

Keywords: failed state, tribalism, Iraq, sectarian violence

\section{Introduction}

The collapse of the regime in Iraq in 2003 by US forces brought a vacuum of state institutions. Number of casualties of both US soldiers and Iraqi civilians increased after "the end of the major combat" that Bush administration declared in 1 May 2003 and reached to the level of "civil war" during 2006-2007, which was understood as "sectarian conflicts". In order to end such increase of sectarian hostility and anti-US violence, the US authorities and Iraqi government empowered the tribe leaders in Anbar province to stabilize the security and end the anti-US Sunni revolt and to fight Al-Qaeda ${ }^{1}$ in Iraq. In this process, however, then the Prime Minister Nouri Al-Maliki ${ }^{2}$ introduced his own way to utilize the tribal groups, supporting new tribe leaders in Baghdad that mainly belong to Shia sect for the propose to create his supportive body there. In this way, the importance of tribes and tribe leaders in the social and political life of Iraq increased after 2003 in various phases.

This article tries to explain the role of tribal society in Iraq during Al-Maliki role 2006-2014, and how political actors try to manipulate the power and influence of tribal groups in Iraq. It is true that the rulers in Iraq historically used the tribal forces in order to use them as a political tool, from the era of Ottoman to the regime of Saddam Hussein. However, we can find a difference in the pattern of tribal policy in the post-2003 regime,

Haidar Reda, Ph.D. student, Graduate School of Humanities and Studies of Public Affairs, Chiba University, Chiba, Japan.

1 Al-Qaeda in Iraq appeared for the first time in 2004 when al-Zarqawi, a Jordanian-born militant leader, already leading insurgent attacks against foreign troops and Shia in Iraq, formed an alliance with Al-Qaeda.

${ }^{2}$ Nori Kamil Al-Maliki is an Iraqi Shia politician who was Prime Minister of Iraq from 2006 to 2014. He is secretary-general of the Islamic Dawa Party. 
compared to the historical usage before. The essential questions to be asked here are; why the way of tribal mobilization is new in Al-Maliki administration (2006-2014), comparing with those of previous regimes? How do tribal leaders contribute to stabilizing and de-stabilizing the country after 2003 ?

Theoretical framework of this article is based on Robert I. Rotberg failed state theory. Failed states suffer from limited power to influence social control. According to Robert I. Rotberg (2007), failed states can be characterized as undergoing violent conflict. Often the state has little to no effective control over outlying areas and little connection to, or support from, most of the population. Collapse states are extreme cases of failed states, in which there is a vacuum of authority, and what little provision of political goods does exist tends to be provided on a localized level by forces that have little control at the state level. In the aftermath of state collapse, the geographical boundaries are meaningless and decision-making power leaks out to neighbors and international actors as they are dragged into the conflict (Dodge 2007, p. 26).

In the case of Iraq, failed state theory can be best applied in the post-2003 period. In failed state, political elite focuses on military and security solutions instead of political reforms (Lynch 2016, p. 34). The most dramatic case was that of Nouri Al-Maliki creating new tribe leaders and tribe assembly in Baghdad and other Shia areas in the south to stabilize the security and to gain political and public support.

Traditionally Iraq, the Arabian Peninsula, and North Africa share in common that they are based on tribal societies and tribal nature remains there. The word tribe ('ashīrah) refers to a group of people sharing in common same male ancestor and the word Shaykh refers to tribe leader. Shaykhs usually belong to strong families with strong influence over the society (Al-'Amary, 1992, pp. 28-31).

\section{Tribal Uprising Against Al-Qaeda}

During this quasi-civil war in 2006-2007, the US forces and the new Iraqi government had no control over many territories especially in the north west of Iraq. They began in 2007 arming the tribes to fight against Al-Qaeda, especially in Anbar Province, west to Baghdad where the most population are Sunni and north of Babil Province, suburb of Baghdad, in order to end the anti-US Sunni revolt, Al-Qaeda, and stabilize those territories (Gartenstein-Ross \& Jenson, 2015).

Sahwa al- 'A 'shä'ir (Tribal Awaking) was established in order to fight against Al-Qaeda in al-Anbar city, north-west of Baghdad. Shaykhs (tribal leaders) gathered in Anbar and announced the Sahwa in September 2006 to fight against Al-Qaeda. There are many factors that made the tribes to rise against Al-Qaeda. First, al-Zarqawi, and other leaders of Al-Qaeda also rejected any kind of political formations because they believed all matters should be solved under the leadership of the Al-Qaeda. Therefore, the leaders of Al-Qaeda tried to eliminate the tribe leaders and make the tribesman loyal only to Al-Qaeda (Gartenstein-Ross \& Jenson, 2015, 103-104). Second, Al-Qaeda forbade Sunnis to join the new political life which made the new government majority Shia and Kurds. Moreover, Al-Qaeda organized assassination against Sunni politicians and tribe leaders who joined the new regime, which created conflicts within the tribes because of the revenge system (Benraad, 2011).

The Iraqi government increased the budget for Anbar province and supported the Sahwa with money and weapons. In addition, the tribal leaders asked the US authorities and the Iraqi government to release all prisoners who were kept in prison without charges and deploy tribesmen as the national army. The tribal leaders of Anbar asked the US authorities to deploy more of their tribesmen into the army to stop the central government from sending soldiers from other cities, mainly from Shia cities, to protect the Sunni areas (BBC, 2007). 
This motivated other tribes, especially Shia, to cooperate with the government against the Shia militias, such as al-Mahdi Army, led by al-Sadr Tendency in their towns; the case typically is the battle in Basra between Iraqi army and Mahdi Army on March 2008. This cooperation between the government and the tribes led to stabilization and decline in sectarian tensions between Sunni and Shia. According to witnesses whom the author conducted interviews, regular meetings were organized among Sunni and Shia tribe leaders to discuss the ending and prevention of any sectarian conflict in the future. A Shia interviewee $<A>$ from Baghdad said in November $2017^{3}$,

During the conflict and the rise of militia, we couldn't talk and stop them because they will consider us as betrayers. After Jaysh al-Mahdi (Shia militia) did a lot of atrocities, not only against Wahhabism, but also against us, against Shia for ransom or if there is was a personal problem. Then people realized and began helping the government by providing information. In 2008 we began cooperating with other Sunni Shaykhs to end the violence, because we all are brothers, and to prevent those criminals to create problems.

Another Shia interviewee from Baghdad Shaykh <B> said in November 2017:

We have to end this violence, there is no such thing Shia and Sunni. We are all Arabs; I have many Shia and Sunni members in my tribe here in Baghdad. I protect them all. No one can kill or fight with his own cousin. In Baghdad it's different than rural areas so our main Shaykhs don't really know what's going on here in Baghdad.

The tribal fighting against Al-Qaeda began in Anbar, and then it spread to other rural areas, mainly in Salahuddin, Baghdad, north Babel, and Diyala. The US forces supported also the tribes in these other areas (Al-Malaf Press, 2007). However, beside the expected outcome, fighting against Al-Qaeda, this also increased the clashes between the tribes.

\section{Creation of Majālis al-Asnād}

After the model of Sahwa al-'A'shā'ir was successful in Anbar, the government of Nuri Al-Maliki announced the establishment of Majālis Al- 'asnād in 2008, a Baghdad based council of Shaykhs chosen by the government. The role of this council was not only to provide security assistance and solve the problems among tribes but also to serve as a connection between the people and the government, according to the official website of the Prime Minister Majālis Al-'asnād (2008). Most of these councilors were freshly bestowed with the title of a Shaykh by the prime minister office, but all of them were chosen according to their loyalty to the government. They are called as "new Shaykhs" among the tribal society in order to differentiate from traditionally established tribal system. Thus, the author used the term "New Shaykh" to describe this newly appointed tribal leaders politically selected by the post-war regime in this paper. According to the witnesses, the new Shaykhs received identification cards as well from the ministry of interior to prove their new title and role. In November 2017, an interviewee from Baghdad $<$ C $>$ said:

I'm a Shaykh of a fakhdh, our general Shaykh i.e., Shaykh al-'ashīra asked me to be Shaykh in Baghdad to take care of our people because there are many people who claim to be Shaykhs. Those new Shaykhs created many problems because they don't know about our tribal traditions, norms, and laws. Most of them belong to or they are supported by political parties and they claim to be Shaykh just because they have ID issued by the ministry of interior".

\footnotetext{
${ }^{3}$ In 2017, I conducted a field research in Iraq from November 6th to January 25th. For security reasons, I chose not to mention the names of Shaykhs I interviewed. On November 12th, I interviewed Shaykh A in Baghdad. On November 20th, I interviewed Shaykh B in Baghdad. On November 21st, I interviewed Shaykh C in Baghdad. On November 10th, I interviewed Shaykh D in Baghdad. On January 24th, I interviewed person E in Baghdad. On November 19th, I interviewed Syed F in Baghdad. On November 26th, I interviewed Shaykh G in Babel. And, Shaykh H. was interviewed on November 17th in Baghdad.
} 
The Maliki tribal policy created conflicts between different tribes and even among people of the same tribe. Interviewees point out the presence of three types of Shaykhs under and after Al-Maliki administration: original Shaykhs (who inherited the title from their fathers), 1990's Shaykhs, appointed by Saddam Hussein, and 2003's Shaykhs, nominated by Nori Al Malik. An interviewee, for example, Shaykh $\langle\mathrm{D}\rangle$ from Baghdad said, in November 2017:

I'm not actually a Shaykh, but our Shaykh asked me to be his representative in Baghdad. The violence in 2006-2007 ended because people got tired of the militia's behavior towards them and began helping the security forces, which also increased the government's power. Both Sunni and Shia tribal leaders put aside their hatred for each other and started communicating, supporting the official forces and solving whatever conflicts they could through tribal norms. Al-Maliki continued a similar policy to Saddam's by creating Shaykhs. We call them Shaykhs of 1990s. Al-Maliki also began creating new tribe leaders to support him and he claimed they helped ending violence, but in fact they did not, they formed groups similar to mafias. Every day we hear of tribal violence in Baghdad, they are using gunfire. It wasn't like that before.

The third type of Shaykhs mentioned above is also called by some people "rental tribe leaders". It means that these Shaykhs, in exchange for money, will represent whoever is in need of their services, usually wrongdoers, and try to solve any problem the tribal way. These practices are, in truth, rejected by the tribal societies. An interviewee <E>said:

Last year a group of people robbed my brother. We sued them (they have some footage of the robbers caught by a security camera), but the case is still going in the court. The Judge asked us if we have tried to solve it the tribal way. The truth is that we tried to do so, but they sent us rental tribal leaders which we can't and won't accept. However, the Judge postponed the case for another week hoping it would be solved through tribal leaders.

Moreover, a tribal man ${ }^{4}$ belonging to al-Hachim tribe provided me with a copy of a letter signed by the original tribe leaders of al-Hachim, declaring that there is no tribe leader in Baghdad and that the new tribal leader named (Sattar Karim) does not represent al-Hachim tribe in Baghdad. At the end of the letter, it is mentioned that a copy of the letter was given to the Ministry of Interior, Department of Tribal Affairs. During the field research in Iraq on 2017-2018, the author attends several tribe meetings and heard of similar cases of the new tribe leaders in Baghdad creating even more problems due to their lack of understanding of tribal norms.

Failing to establish strong state against society, Al-Maliki too, as others did before him, relied on tribes to stabilize the country. However, many old tribe Shaykhs believed he tried to gain political influence and power. In November 2017, Shaykh $<\mathrm{G}>$ from Babel an interviewee described the situation saying:

I'm Shaykh, son of Shaykh. Tribesmen come to us, from the city and villages, for help if they have any problem. The problems increased after 2003, particularly related to violence. We could solve many problems using our connections with other real tribe leaders Shia and Sunni. However, the main problem we faced was that of some new tribe leaders that were hired by Al-Maliki or the government. Many of the new tribe leaders created problems because they don't know our rules. Moreover, other political parties began to create new tribe leaders just to gain power and to show popularity.

Following an example from Baghdad, Majālis al-Asnād offices were created all over Shiite areas in Southern Iraq, which created problems with the ruling political parties of these areas. The governor of Al Diwaniyah even threatened to imprison anyone planning to open any Majālis al-Asnād other than his own

\footnotetext{
${ }^{4}$ During my field research on January 2018, I attend a tribal meeting and met Firas al-Hachimi. On February 2019, he sent me a copy of the letter.
} 
(Azzaman, 08-14-2008). Every political party started appointing new Shaykhs and creating similar councils to gain popularity.

\section{The Consequences of Al-Maliki’s Retribalization Policy Since 2006}

Using a tribe to gain political power or to stabilize an area was not a new strategy in Iraq. The novelty of Al-Maliki's policy is based on two points: The first is reliance on newly appointed tribe leaders in urban areas, as opposed to the Ottoman's, British, and Saddam's regimes which relied on tribes only in rural areas. Second, he relied mainly on Shia tribe leaders.

The new tribe leaders do not have in fact any real social power, beside the support from the political parties that appointed them or from the militias. This can be also understood from the words of an interviewee $<$ F> who belong to Sādah family ${ }^{5}$ from Baghdad, in November 2017:

I often become a mediator when there is a fight between tribes. The tribal problems increased in Baghdad recently, particularly since 2008. The problem is that after 2008 many Shaykhs appeared from nowhere and created a few groups around them to fight. Those Shaykhs don't know much about the rules of Shaykhs. However, some of them get some support from some political parties. We are trying not to turn any tribal conflict into a sectarian one because it will be hard to solve, and it might spread to other areas. We get support from the authorities; we visit the police officers and army to talk about what's going in the area.

According to the interviewees, soon after forming Majālis al-Asnād in 2008, various persons started claiming that they were new Shaykhs and they formed new clans. People who needed protection were hiring mainly the clansmen of these new "Shaykhs". This made the new tribe leaders and their groups function like mafia. Any kind of violence could be solved through the tribe instead of the state's justice. According to the witnesses, there were cases of tribesmen carrying guns and attacking houses or buildings belonging to people from other tribes, while the police and the army remained silent. This made the people seek tribe's justice more than state justice. In November 2017, Shaykh $<\mathrm{H}>$ from Baghdad summarized it by saying:

I tried to solve some problems; people rather prefer tribal solutions than governmental help. If there is a tribal conflict or any kind of problem and tribesmen attack one house using guns, the police won't intervene because they believe it will be solved through tribe leaders. There are even people from other tribes both Sunni and Shia that came to me asking for help and protection. Today, the protection of tribe is the most important thing to get.

The tribes became stronger after the creation of Majālis al-Asnād and started creating more violence, especially in Baghdad. A declaration was signed in February 2018 by Minister of Interior and some tribe leaders. The tribal leaders promised the government that not to attack the families of people who wronged in their eyes or other tribes using guns, nor to threaten them to leave the city (Baghdad Today, 2018).

The tribes in Anbar grew stronger after the creation of Sahwa, which made Nori Al-Maliki afraid of them. In 2008, he began arresting members of Sahwa to weaken their forces (Azzaman, 08-23-2008). Meanwhile, he kept supporting the Shia tribe leaders that were loyal to him. The opposition political parties consider this act of Al-Maliki and his party as means to gain more power (Al Mada, 09-13-2013). However, most of the political parties and Shia militias began creating new tribe leaders and support them in return those tribe leaders support these parties.

\footnotetext{
5 The Sādah family claim to be descendants of the Prophet Muhammed, to be a Sayyid (singular) is a matter of birth. In a way, Sādah can be categorized as a part of tribal society and as a part of religious circle, and it played a role to bridge between the two.
} 
Soon after the U.S. troops withdrew from Iraq in December 2011, Al-Maliki and his government issued an arrest warrant for the Sunni politician, vice president and the leader of the Iraqi Islamic party Tareq Al Hashimi, who fled the country in December 19th, 2011. It was followed by the arrest the bodyguard of another Sunni political leader and finance minister, Rafi' Al Essawi in 2012, by counterterrorism forces controlled by Al-Maliki. Moreover, a Sunni politician and parliament member Ahmad Al Alwani was arrested after clashes occurred with the counterterrorism forces (Adnan \& Arango, 2012).

Sunnis in Anbar city began protesting against the government as they considered these acts were against Sunni people. The tribe leaders in Anbar supported these protests by providing them with daily meals and daily speeches encouraging people to join the crowd and demand their right and accuse the Shia-led government of being sectarian (The Civil-Military Fusion Centre [CFC] April, 2013). On the other hand, Al-Maliki accused the protest leaders of inciting violence, sectarianism, and sympathy for Al-Qaeda. The government lost control of many territories in Anbar after the protest turn to violence and some soldiers were killed. Moreover, a Sunni tribe leader in Anbar, Ali Hatem Al Sulaiman ${ }^{6}$, claimed to be the head of the Tribal Military Council, which was also called Tribal Revolutionary He supposed that the council will get rid of the Shia-led government and he be in charge of the security in Anbar (Gartenstein-Ross \& Jenson, 2015).

This led to a split among Sunni tribes in Anbar on how to address this crisis. The head of Sahwa, Abu Risha, decided to coordinate with Al-Maliki to end the crises (Ali Inoma, 2014). Thus, Maliki policy in 2011 produced a tribal conflict among Sunni tribes and political parties in Anbar over the leadership (Alhayat, 2018). The Maliki policy towards the tribes had a big impact on the relationship among the tribal societies in Iraq.

\section{Conclusion}

After the US invasion to Iraq, the state was newly constructed without solid social supportive base. Therefore, the US authorities and Iraqi government had to rely on the tribes to stabilize the state, which gave the tribes an opportunity to become an essential authority. The US authorities cooperated with the tribes, especially Sunni tribes, to fight against Al-Qaeda. To balance the power between Sunni and Shia tribes, Al-Maliki created new tribal leaders and formed what it is called Majālis al-Asnād.

Moreover, the tribal policy from 2008 is the result of social transformation of the Iraqi society, particularly in the urban areas. The failed and collapsed state in Iraq after 2003, allowed the increasing number of non-state actors in Iraq to be more and more active, such as sectarian groups, tribal groups, and mafia. The state started providing Shaykhs with weapons, money, and authority over their tribesmen to help decrease and end sectarian violence and to stabilize the security. The result is that these actions ended the sectarian violence, but they also tribalized the society and determined people to seek tribal justice over state justice.

The implication of Al-Maliki tribal policy is, first, that it created conflict between new and old Shaykhs; second, it tribalized the urban areas particularly in Baghdad. Third, instead of relying on state security, people and even government relied on tribal society to solve problems among people and stabilized the security. However, Al-Maliki did not take advantage of security stabilized after 2008 and do political reformation but instead he relied on the sectarian and tribal groups which led to violence again in 2011.

\footnotetext{
${ }^{6}$ Ali Hatem al-Sulaiman is a Shaykh of al-Dulaimi tribe in Anbar. He stablished the tribal military council in 2014 to fight against the Shia-led government, for more details see https://is.gd/vSYDzk.
} 


\section{References}

Adnan, D., \& Arango, T. (2012). Arrest of a Sunni Minister's bodyguards prompts protests in Iraq. The New York Times. Retrieved 7/20/2018 from https://is.gd/136rye

Al-'Amry, T. A. (1992). Mawsw'ah al- 'ashāir al- 'arāqyah. Baghdad: Dar Al-Shu'wn Al-thqafyah Al-'amah.

Alhayat. (2018). Retrieved 8/28/2018 from https://is.gd/Mu9dD3

Ali Inoma. (2014). Anbar witnesses political divide amid ongoing clashes. AlMonitor. Retrieved 7/11/2018 from http://www.almonitor

Al-Malaf Press. (2007). Retrieved 7/20/2018 from https://is.gd/uhqlol

Baghdad Today. (2018). Retrieved 12/22/2018 from https://is.gd/mwhfIE

BBC. (2007). Retrieved 6/24/2018 from https://is.gd/ojqVh2

Benraad, M. (2011). Iraq's tribal "Sahwa": Its rise and Fall XVIII. Retrieved 8/20/2018 from https://is.gd/7KYguI

Dodge, T. (2007). State collapse and the rise of identity politics. In M. E. Bouillon, D. Malone, and B. Rowswell (Eds.), Iraq: Preventing a new generation of conflict. Boulder, London: L. Rienner (A project of the International Peace Academy).

Gartenstein-Ross, D., \& Jenson, S. (2015). The role of Iraqi Tribes after the Islamic State's Ascendance. Retrieved 5/20/2018 from https://is.gd/M8tuoB

Lynch, M. (2016). Failed states and ungoverned spaces. The ANNALS of the American Academy of Political and Social Science, 668(1), 24-35. doi: 10.1177/0002716216666028

Majālis al-Asnād. (2018). Prime minister official website. Baghdad. Retrieved 7/15/2018 from https://is.gd/VZdN05

Rice, S. E., Graff, C., \& Pascual, C. (2010). Confronting poverty: Weak states and U.S. national security. Washington, D.C.: Brookings Institution Press.

Rotberg, R. I. (2007). When states fail: Causes and consequences. Princeton: Princeton University Press.

The Civil-Military Fusion Centre (CFC). (April, 2013). The re-awakening of Anbar. Retrieved 8/22/2018 from https://is.gd/O93wbv 